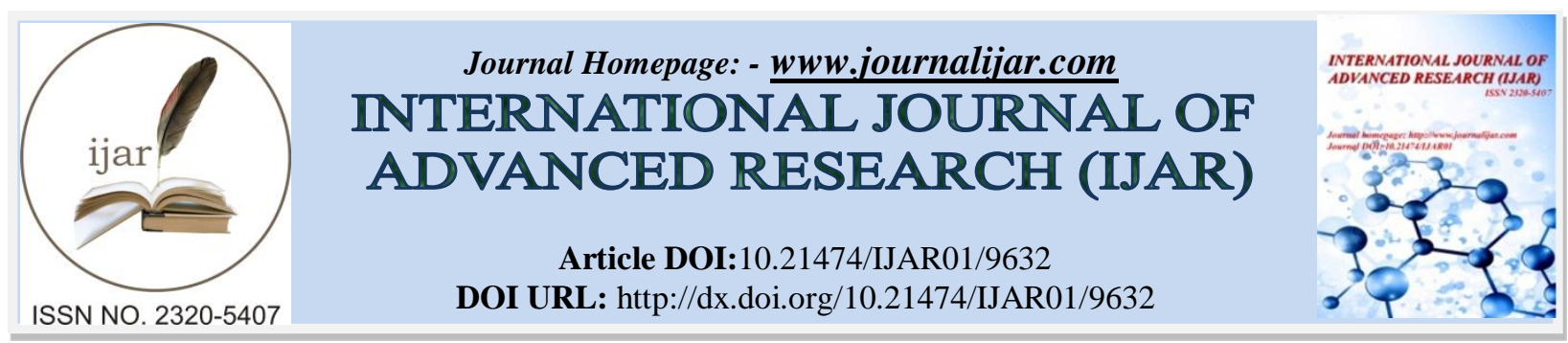

RESEARCH ARTICLE

\title{
MEASURING STUDENT SATISFACTION THROUGH SERVQUAL: EMPIRICAL STUDY AT BINAWAN UNIVERSITY.
}

\section{R. Ervin Agung Priambodo ${ }^{1}$ and E. Michael Bayudhirgantara ${ }^{2}$}

1. Lecture, Post Graduate Program, High School of Governmental Science - State Servant, Jakarta, Indonesia.

2. Lecture, Post Graduate Program, Department of Management Science, Faculty of Economic and Business, Mercu Buana University, Jakarta, Indonesia

\section{Manuscript Info}

(..........................

Manuscript History

Received: 02 July 2019

Final Accepted: 04 August 2019

Published: September 2019

Key words:-

Student satisfaction, service quality, higher education.

\begin{abstract}
This study aims to identify the student satisfaction through service quality in the higher education. The study used a descriptive approach involving 144 students from Binawan University. Data collection using questionnaire with a 5-point Likert scale and collected data were analyzed using SERVQUAL and Cartesian Diagrams. The results of this study indicated that in general the quality of service at Binawan University based on students' perceptions is quite low and and shows gaps in each service attribute. These findings indicate that students are not satisfied with the services provided by Binawan University. The analysis from level of importance indicated that the dimensions of service most considered important by students are reliability, followed by tangible, responsiveness, assurance, and empathy. The improvement of service quality shuld based on the results of Cartesian Diagrams with focus on service attributes in quadrant $\mathrm{A}$.
\end{abstract}

Copy Right, IJAR, 2019,. All rights reserved.

\section{Introduction:-}

Higher education is a service sector with dynamic and competitive characteristics (Choudhury, 2015; Dehghan, Dugger, Dobrzykowski, \& Balazs, 2014) and develops exponentially and rapidly (Latif, Latif, Farooq Sahibzada, \& Ullah, 2019; Nadiri, Kandampully, \& Hussain, 2009). Education has also been categorized as part of the service industry (Galeeva, 2016) and has become a business with multi-billion dollar (Cheung, Yuen, Yuen, \& Cheng, 2011). Therefore, the education sector is seen as a promising business that raises many business people. Particularly in Indonesia, competition is appears especially in private higher education with a total of 3,940 universities which also have to compete with 372 public universities. The government also plans to provide opportunities for foreign universities to open lectures in Indonesia which will increase the rapid of competition.

Service quality is an important factor for strengthening performance and competitiveness (Hill, 1995; Štimac \& Šimić, 2012), being the key to success for organizations (Abdullah, 2006; Lin, Chan, \& Tsai, 2009), and being one indicator of higher education quality (Uka, 2014). Thus how well the educational experience provided by higher education institutions will determine the level of student satisfaction (Chanaka Ushantha \& Samantha Kumara, 2016). Therefore, universities need to maintain and improve service quality continuously (Clemes, Cohen, \& Wang, 2013; Teeroovengadum, Kamalanabhan, \& Seebaluck, 2015). There are a number of aspects that encourage higher education to improve services, such as need for innovation, need for process improvement, customer satisfaction,

Corresponding Author:- R. Ervin Agung Priambodo

Lecture, Post Graduate Program, High School of Governmental Science - State Servant, Jakarta, Indonesia 
global and national forces, higher standards, complexity of the system, budget crunches, need for safeguard investments, and need for a measurement system (Sunder, 2016).

The principle must be held today to improve the quality of educational services is to make continuous improvements, focus on the interests of stakeholders, and focus on increasing student satisfaction (Tan \& Kek, 2004). Quality of service is important because in a number of studies has been proven to have an effect on student loyalty and satisfaction (Ali, Zhou, Hussain, Nair Kumar, \& Ragavan, 2016; Annamdevula, 2017; Annamdevula \& Bellamkonda, 2016; Dehghan et al., 2014; Helgesen \& Nesset, 2007; Osman \& Saputra, 2019; Sharabati, Alhileh, \& Abusaimeh, 2019), where student satisfaction and loyalty are important factors in the education service industry that will determine the survival of higher education.

Higher education provides services to the community in the form of higher education with providing teachinglearning processes and research. The main product of higher education is the knowledge provided to the community in the form of higher education services, so that the main business of higher education is science. The main service users of higher education are students. Therefore, universities must be able to provide satisfying service to students as the main service users of higher education. Students are also major stakeholders in the higher education environment (Latif et al., 2019) and are positioned as customers (Hill, 1995; Yildiz \& Kara, 2015) so they should get priority by getting excellent service. Higher education must be able to meet every students expectation for the services provided so that student satisfaction can be realized.

As an important factor in managing higher education, each higher education needs to continually evaluate the quality of services in order to know the effectiveness. Evaluation is important to understand student needs for service attributes in higher education (Zafiropoulos \& Vrana, 2008), so that each higher education can formulate appropriate strategy to improve service quality. This study aims to evaluate the student satisfaction at Binawan University through SERVQUAL approach. This evaluation step is important in an effort to develop the competitiveness of Binawan University for survive and success in the competition.

\section{Literature Reviews:-}

\section{Service Quality}

Many reviews about the notion of service quality as revealed by Hoffman and Bateson (2011, p. 324) "service quality refers to an attitude formed by a long-term, overall evaluation of a firm's performance". This definition shows that service quality is an evaluation product for a long time and involves various aspects of the services provided by the company. The evaluation is based on experience and other information received so that someone can provide an assessment of how well the services provided by a company. Another opinion shows that "service quality is a level of excellence offering by customers where control over the level of excellence aims to meet customer needs" (Keillor, Wilkinson, \& Thomas, 2007, p. 163).

Service quality also refers to the ability of service providers to improve the services provided (Perry \& Thomson, 2004) and the ability to understand customer needs by trying to exceed customer expectations (Hollins \& Shinkins, 2006). Customer expectations can be achieved by providing total, accurate and in accordance with what has been promised service (Andrews, Boyne, Law, \& Walker, 2012).

In the context of higher education, the quality of service is related to the extent to which the service attributes provided are in accordance with what is determined by students (Sultan \& Wong, 2013). In this case students conduct an assessment based on the perceived experience of the service attributes that have been determinate (El Alfy \& Abukari, 2019). Service quality in higher education also refers to the difference between expectations and the real service perceived by students (O’Neill \& Palmer, 2004). Each student has basically determined the service attributes that are considered important to be fulfilled by the campus.

According to Fitzsimmons dan Fitzsimmons (2011) there are two main aspects of service quality, namely expected service and perceived service, so the extent of the quality of a service can be identified by comparing the expectation and perceived service. This is also in line with what was stated Choudhury (2015) that service quality refers to the difference in scores between expectations and perceptions of a service. The concept basically refers to the expectation confirmation theory developed by Oliver $(1977,1980)$ which evaluates satisfaction as a function between expectations and what is felt. 
The concept of expectations and perceived service is also the basis in the formulation of service quality scales. One scale that has been widely used to measure service quality is SERVQUAL developed by Parasuraman, Zeithaml and Berry $(1985,1988)$. SERVQUAL is not only applied to commercial companies, but has also been widely applied to measure the quality of service in tertiary institutions (Chui, Ahmad, Bassim, \& Zaimi, 2016; Dado, Petrovicova, Riznic, \& Rajic, 2011; Đonlagić \& Fazlić, 2015; Li \& Kaye, 1998; Smith, Smith, \& Clarke, 2007; Stodnick \& Rogers, 2008). There are five dimensions in SERVQUAL, namely: tangibles, reliability, responsiveness, assurance, and empathy (Zeithaml, Parasuraman, \& Berry, 1990). The SERVQUAL scale consists of 22 statement items consisting of two parts, namely expectations and actual service. The SERVQUAL scale is also equipped with a form of importance so that respondents can provide a percentage on each dimension according to the priority scale or the level of relative importance felt by the respondent.

\section{Student Satisfaction}

Satisfaction has been considered as one of the most important theoretical and practical issues for most marketers and customer researchers. There is no definition of satisfaction that is unanimously accepted, but of all the proposed definitions generally agree that the concept of satisfaction implies the need to achieve the goals to be achieved by the customer (Martín-Consuegra, Molina, \& Esteban, 2007). In other words, satisfaction can be realized when customer expectations can be fulfilled. This is in line with was stated by Sumaedi et al. (2016), customer satisfaction is a construct that represents a feeling of advantageous or unfavorable customer resulting from its assessment of the difference between the overall performance of goods or service producers with their expectations.

Espejel, Fandos, and Flavián (2008) mention three components contained in the concept of satisfaction. First, an emotional or cognitive response. Second, responses related to specific focus, such as expectations, products and consumption experiences. Third, the response that occurs at a certain time. The three things are basically also not much different from previous concepts that still emphasize things like expectations and experience or performance of a product or service.

In the context of higher education, students are positioned as major customers (Hill, 1995; Latif et al., 2019; Sultan \& Wong, 2013; Yildiz \& Kara, 2015), so student satisfaction is an important measure of service performance in higher education (Barnett, 2011). Student satisfaction is a short-term attitude as a result of his experience of educational services provided by higher education (Elliott \& Healy, 2001). Student satisfaction is also a form of liking for subjective evaluation of the experiences felt during education and as a repetitive process in life on campus (Elliott \& Healy, 2001).

When referring to the concept of satisfaction above, then in the service industry such as higher education, service quality is the main antecedent of satisfaction. Many previous studies also put quality as an antecedent of student satisfaction (Ali et al., 2016; Annamdevula, 2017; Annamdevula \& Bellamkonda, 2016; de Jager \& Gbadamosi, 2013; Dehghan et al., 2014; Khoo, Ha, \& McGregor, 2017; Sharabati et al., 2019). Therefore, how good the quality of services provided by higher education can indicated of how satisfied students.

\section{Research Methods:-}

This study aims to measure student satisfaction through the SERVQUAL approach, namely by looking at the service gap between expectations and perceived services. The study was conducted descriptively by survey method. The survey was conducted at Binawan university with an accessible population of 226 students. In determining the number of samples using the Slovin formula which produces a minimum sample of 144 students. The sampling technique using purposive with the criteria of students who have taken college in the sixth semester or more. Students who are already at the sixth semester level are considered to have enough experience and have felt a lot of various services provided by the campus.

The research instrument in the study used SERVQUAL developed by Parasuraman, Zeithaml and Berry (1985, 1988). The SERVQUAL questionnaire consists of 22 items divided into two groups, namely expectations and actual service. In this study the instrument consisted of 3 parts, namely the profile of respondents, service quality, and level of service importance. A 5-point Likert scale is used to provide respondents' score scores. Data analysis uses service gap analysis, which is by calculating the difference between the actual service score and the expected service. Cartesian Diagram is also used to mapping the service attributes in each quadrant. 


\section{Results and Discussion:-}

Demographic breakdown

Table 1. shows that more than half (54.2\%) of the respondents in this study were male. From its age, the majority (65.3\%) were 21-22 years old and most of them took semester $7(36.1 \%)$. While based on the chosen study programs, most of them came from economic and business study programs (39.6\%).

Table 1:- Demographic description of the sample $(n=144)$

\begin{tabular}{|l|c|c|}
\hline Description & Frequency (F) & Percentage (\%) \\
\hline Gender & 78 & 54.2 \\
Male & 66 & 48.8 \\
Female & & \\
\hline Age & 2 & 1.4 \\
20 and below & 94 & 65.3 \\
$21-22$ & 43 & 29.8 \\
$23-24$ & 5 & 3.5 \\
25 and above & & \\
Semesters & 47 & 32.6 \\
6 & 52 & 36.1 \\
7 & 39 & 27.1 \\
8 & 6 & 4.2 \\
9 and above & & 13.2 \\
\hline Program of study & 19 & 9 \\
Nursing and midwifery & 13 & 22.2 \\
Public health & 32 & 39.6 \\
Science and technology & 57 & 7.7 \\
Economy and business & 11 & 8.3 \\
Social welfare & 12 & \\
Psychology & & \\
\hline
\end{tabular}

\section{Level of students importance}

The results of calculating the scores of students' importance levels refer to the third part of the SERVQUAL questionnaire, where respondents are asked to allocate scores for the five dimensions of service according to their portion of interest so that the whole number is $100 \%$. The calculation results obtained are listed in Table 2 .

Table 2:- Level of students importance

\begin{tabular}{|c|l|c|}
\hline No. & Dimensions & Level of importance (\%) \\
\hline 1 & Reliability & 23.83 \\
\hline 2 & Assurance & 17.57 \\
\hline 3 & Tangible & 21.74 \\
\hline 4 & Empathy & 16.49 \\
\hline 5 & Responsiveness & 20.37 \\
\hline
\end{tabular}

The highest level of importance refers to the reliability dimension of $23.83 \%$. This means that the attributes that are considered important by students are the accuracy of doing the things that have been promised, providing services from the start in a professional manner, providing services as promised, good faith to solve student problems, and the accuracy of recording data. The second order of importance is the tangible dimension (21.74\%). The tangible dimensions include the ownership of cutting-edge and modern equipment, the attractiveness of campus physical appearance, neat appearance of lecturers and staff, and appearance of material or physical supporting campus services as needed. 
The third order of importance that becomes the preference of students is the responsiveness dimension (20.37\%). This dimension consists of four attributes, namely telling exactly when services will be provided, service delivery quickly and accurately, staff who are not too busy in responding to student requests, and the readiness of the campus to assist students. The fourth level of importance according to student assessment is the assurance dimension (17.57\%). These dimensions include the knowledge possessed by campus staff, staff attitudes that instill confidence in students, a sense of security in the campus environment, and staff courtesy to students. The last order of importance according to students is empathy dimension (16.49\%). This dimension involves several attributes, namely individual attention to students, campus staff giving personal attention to students, staff understanding of students 'interests, staff understanding of students' specific interests, and flexible working hours according to student needs.

\section{Weighted SERVQUAL Score (WSC)}

WSC is a multiplication of service quality scores with the score of the level of importance for each dimension (Table $3)$. The results of WSC sequentially from highest to lowest are the dimensions of empathy (-0.198), assurance ($0.260)$, tangible $(-0.265)$, responsiveness dimension $(-0.308)$, and the dimension of reliability $(-0.355)$. The overall average score is -0.277 . The level of service fulfillment show the highest score refers to the empathy dimension (73.3\%), while the lowest score refers to the responsiveness dimension $(65.9 \%)$. While for the overall average score is $69.3 \%$. These results indicate that the fulfillment rate of services is only $69.3 \%$ so that there are still $30.7 \%$ that cannot be met by the campus.

Table 3:- Weighted SERVQUAL Score

\begin{tabular}{|c|l|c|c|c|c|c|c|}
\hline No. & Dimensions & Expectation & Perceived & SERVQUAL & $\begin{array}{c}\text { Level of } \\
\text { fulfillment }\end{array}$ & $\begin{array}{c}\text { Level of } \\
\text { importance }\end{array}$ & WSC \\
\hline 1 & Reliability & 4.47 & 2.98 & -1.49 & 66.7 & 0.2383 & -0.355 \\
\hline 2 & Assurance & 4.61 & 3.13 & -1.48 & 67.9 & 0.1757 & -0.260 \\
\hline 3 & Tangible & 4.51 & 3.29 & -1.22 & 72.9 & 0.2174 & -0.265 \\
\hline 4 & Empathy & 4.49 & 3.29 & -1.20 & 73.3 & 0.1649 & -0.198 \\
\hline 5 & Responsiveness & 4.43 & 2.92 & -1.51 & 65.9 & 0.2037 & -0.308 \\
\hline
\end{tabular}

To interpret WSC values, interpretation categorizations are developed by Mudie and Cottam (1993). WSC values obtained for each dimension are at negative intervals $0.1-1$, so it is said that the service performance for each dimension is smaller than expected. Likewise, overall (-0.277), the WSC value is also at the same interval, thus indicating that the performance of the service is smaller than expected.

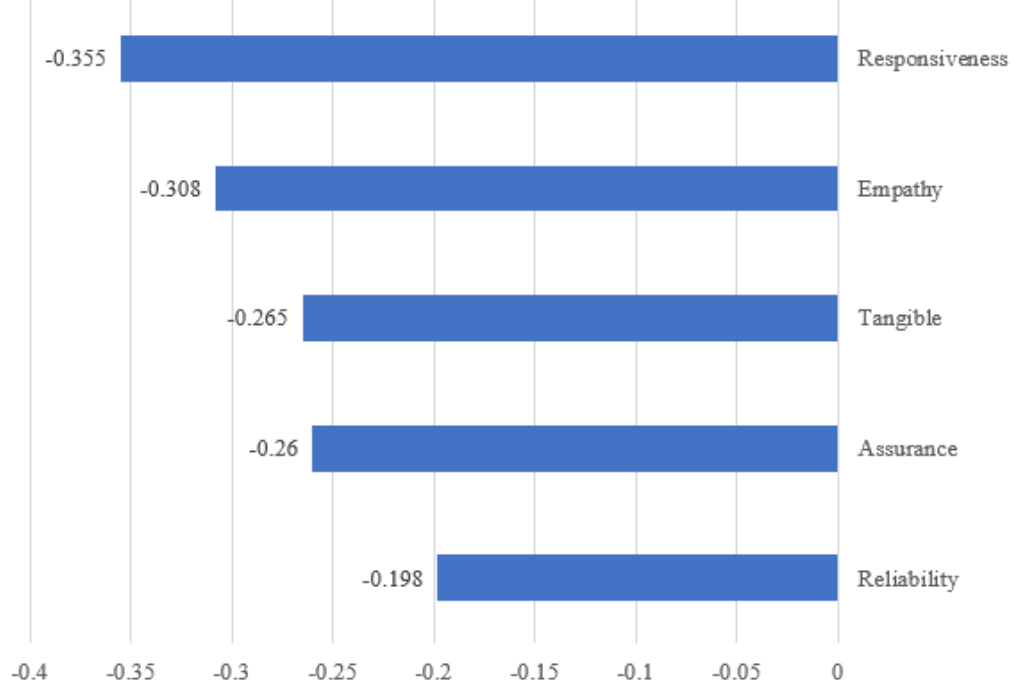

Figure 1:- WSC score ranking 
In Figure 1 it can be seen that there is a mismatch between the level of student importance and the quality of services provided by the campus. Based on the level of importance, the campus should successively prioritize the dimensions of reliability, tangible, responsiveness, assurance, and empathy. While in the SERVQUAL Score, the dimensions of service quality performance that are best fulfilled sequentially are the dimensions of empathy, tangible, assurance, reliability, and responsiveness. This indicates that the campus must pay more attention to the priorities of student and make efforts to improve services according to these priorities. The initial step to determine improvements in service quality can be seen from the SERVQUAL Score or WSC of each dimension. Next, look for the dimension that has the biggest weighted gap or the smallest WSC and then review the attributes that affect the dimension.

\section{Cartesian Diagram}

This analysis is used to determine the position of each service attribute in the Cartesian Diagram according to the coordinates obtained from the expected score $(\mathrm{Y})$ and the perceived service $(\mathrm{X})$. The expectations and perceived service scores for each student service attribute are shown in Table 4.

Table 4:- Scores of expectation and perceived service

\begin{tabular}{|c|l|c|c|c|}
\hline No. & Service attributes & $\begin{array}{c}\text { Perceived Service } \\
(\mathbf{X})\end{array}$ & $\begin{array}{c}\text { Expected Service } \\
(\mathbf{Y})\end{array}$ & Gap \\
\hline 1 & Accuracy in doing the things that have been promised & 3.00 & 4.43 & -1.43 \\
\hline 2 & Professional service from the start & 3.13 & 4.13 & -1.00 \\
\hline 3 & Providing services as promised & 2.84 & 4.60 & -1.76 \\
\hline 4 & Good faith to solve student problems & 2.63 & 4.63 & -2.00 \\
\hline 5 & The accuracy of recording data & 3.30 & 4.57 & -1.27 \\
\hline 6 & Staff knowledge & 3.78 & 4.74 & -0.96 \\
\hline 7 & The attitude of staff who instill confidence to student & 3.12 & 4.37 & -1.25 \\
\hline 8 & A sense of security in the campus area & 2.84 & 4.68 & -1.84 \\
\hline 9 & Staff politeness to students & 2.77 & 4.66 & -1.89 \\
\hline 10 & Modern and sophisticated equipment ownership & 3.55 & 4.59 & -1.04 \\
\hline 11 & The attractiveness of campus physical appearance & 3.38 & 4.67 & -1.29 \\
\hline 12 & Neat staff appearance & 3.15 & 4.46 & -1.31 \\
\hline 13 & $\begin{array}{l}\text { Availability of material/physical supporting services } \\
\text { as needed }\end{array}$ & 3.08 & 4.30 & -1.22 \\
\hline 14 & Individual attention to students & 3.13 & 4.53 & -1.40 \\
\hline 15 & Staff pay personal attention to students & 3.13 & 4.10 & -0.97 \\
\hline 16 & Staff understanding of students' interests & 3.35 & 4.60 & -1.25 \\
\hline 17 & Staff understanding of students' specific interests & 3.42 & 4.55 & -1.13 \\
\hline 18 & $\begin{array}{l}\text { Flexible working hours and according to student } \\
\text { needs }\end{array}$ & 3.44 & 4.69 & -1.25 \\
\hline 19 & Tell when exactly the service will be provided & 2.82 & 4.61 & -1.79 \\
\hline 20 & Providing services properly and appropriately & 3.20 & 4.33 & -1.13 \\
\hline 21 & $\begin{array}{l}\text { Staff are not too busy in responding to student } \\
\text { requests }\end{array}$ & 2.50 & 4.56 & -2.06 \\
\hline 22 & Willingness to help students & 3.17 & 4.22 & -1.05 \\
\hline Average & 3.12 & 4.50 & -1.38 \\
\hline
\end{tabular}

Based on the scores obtained, it is known that all of service attributes at Binawan University are negative, thus indicating that none of the service attributes can be given in accordance with student expectations. This result also shows that students are not satisfied with every service attribute provided by Binawan University. The average 
expectation score is 4.50 and the perceived service score is 3.12 . The average value becomes the intersection point dividing the four quadrants as shown in the Cartesian Diagram Figure 2.

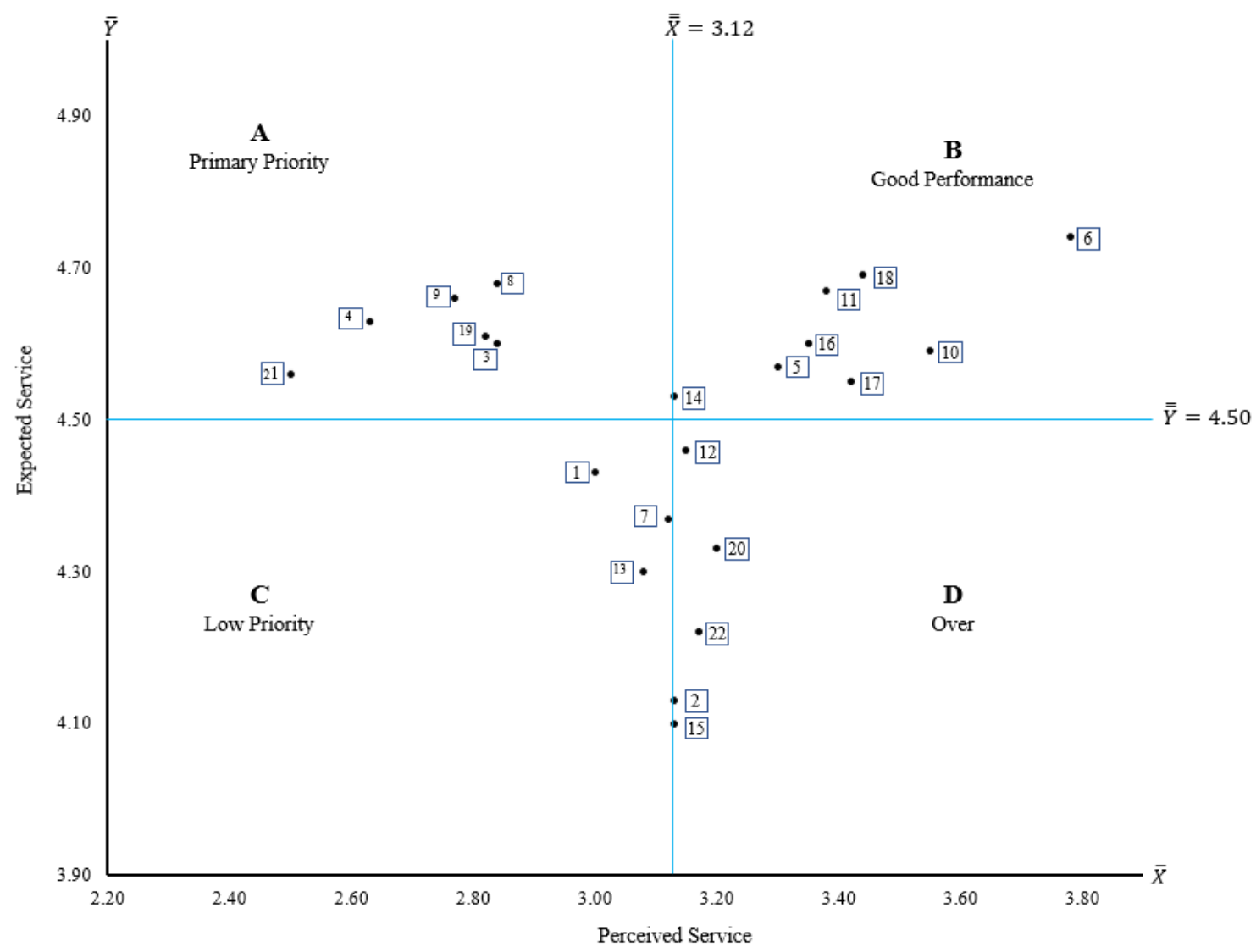

Figure 2:- Cartesian Diagram

Quadrant A is a primary priority, indicated that a high expectations of students to the service attributes, but an actual performance of the service is low. The service attributes included in this quadrant are providing services as promised, good faith to solve student problems, a sense of security in the campus area, staff politeness to students, tell when exactly the service will be provided, staff are not too busy in responding to student requests.

Quadrant B is called a good performance, indicating that a high expectations of the students to the service attributes and an actual performance of the service attributes is also high. Therefore, the performance on this attributes must be maintained. The service attributes that are in this quadrant consist the accuracy of recording data, staff knowledge, modern and sophisticated equipment ownership, the attractiveness of campus physical appearance, individual attention to students, staff understanding of students' interests, staff understanding of students' specific interests, flexible working hours and according to student needs.

Quadrant $\mathrm{C}$ is low priority, indicated that student expectations are low on the service attributes, while an actual performance of the service is also low. The service attributes included in this quadrant consist of accuracy in doing the things that have been promised, the attitude of staff who instill confidence to student, and availability of material/physical supporting services as needed.

Quadrant D is called over, show that an student expectations are low to the service attributes, but an actual performance of the service attributes is high. The service attributes included in this quadrant consist of professional service from the start, neat staff appearance, staff pay personal attention to students, providing services properly and appropriately, and willingness to help students 


\section{Conclusion and Recommendation:-}

Based on the results of the analysis that has been described, it can be seen that in general the quality of service at Binawan University based on students' perceptions is quite low. All of service attributes have been not fulfilled yet, because each attribute still obtained a negative gap. The results of the WSC analysis strengthen that fulfillment of student expectations is still far from optimal, because the WSC scores of each dimension is negative. These findings indicate that students are not satisfied with the services provided by Binawan University. The analysis of importance level indicated that the dimensions of service most considered important by students are reliability, followed by tangible, responsiveness, assurance, and empathy.

Following up on the results of this study, then Binawan University needs to reduce service gaps so that it can gradually meet student expectations. Improvements can refer to the results from Cartesian Diagram by prioritizing improvements of service attribute in Quadrant A, i.e. by increasing accuracy in fulfilling everything promised to students, improving security in the campus environment, educating campus staff to behave more politely and friendly to students, always informing students complete service schedules on campus, and emphasize staff to be more responsive and always ready in serving students.

\section{References:-}

1. Abdullah, F. (2006). Measuring service quality in higher education: Three instruments compared. International Journal of Research and Method in Education, 29(1), 71-89. https://doi.org/10.1080/01406720500537445

2. Ali, F., Zhou, Y., Hussain, K., Nair Kumar, P., \& Ragavan, N. A. (2016). Does higher education service quality affect student satisfaction, image and loyalty? A study of international students in Malaysian public universities. Quality Assurance in Education, 24(1), 70-94. https://doi.org/http://dx.doi.org/10.1108/QAE-11-2012-0046

3. Andrews, R., Boyne, G. A., Law, J., \& Walker, R. M. (2012). Strategic Management and Public Service Performance. New York: Palgrave Macmillan.

4. Annamdevula, S. (2017). Relationship between service quality, satisfaction, motivation and loyalty: a multidimensional perspective. Quality Assurance in Education, 25(2), 171-188. https://doi.org/10.1108/mbe.2000.26704caa.006

5. Annamdevula, S., \& Bellamkonda, R. S. (2016). The effects of service quality on student loyalty: the mediating role of student satisfaction. Journal of Modelling in Management, 11(2), 446-462. https://doi.org/10.1108/JM204-2014-0031

6. Barnett, R. (2011). The marketised university: Defending the indefensible. In M. Molesworth, R. Scullion, \& E. Nixon (Eds.), The Marketisation of Higher Education and the Student as Consumer. Oxon: Routledge.

7. Chanaka Ushantha, R. A., \& Samantha Kumara, P. A. P. (2016). A Quest for Service Quality in Higher Education: Empirical Evidence from Sri Lanka. Services Marketing Quarterly, 37(2), 98-108. https://doi.org/10.1080/15332969.2016.1154731

8. Cheung, A. C. K., Yuen, T. W. W., Yuen, C. Y. M., \& Cheng, Y. C. (2011). Strategies and policies for Hong Kong's higher education in Asian markets: Lessons from the United Kingdom, Australia, and Singapore. International Journal of Educational Management, 25(2), 144-163. https://doi.org/10.1108/09513541111107579

9. Choudhury, K. (2015). Evaluating customer-perceived service quality in business management education in India: A study in topsis modeling. Asia Pacific Journal of Marketing and Logistics, 27(2), 208-225.

10. Chui, T. B., Ahmad, M. S. bin, Bassim, F. binti A., \& Zaimi, N. binti A. (2016). Evaluation of Service Quality of Private Higher Education Using Service Improvement Matrix. Procedia - Social and Behavioral Sciences, 224, 132-140. https://doi.org/10.1016/j.sbspro.2016.05.417

11. Clemes, M. D., Cohen, D. A., \& Wang, Y. (2013). Understanding Chinese university students' experiences: an empirical analysis. In Asia Pacific Journal of Marketing and Logistics (Vol. 25). https://doi.org/10.1108/APJML-07-2012-0068

12. Dado, J., Petrovicova, J. T., Riznic, D., \& Rajic, T. (2011). An Empirical Investigation into the Construct of Higher Education Service Quality. International Review of Management and Marketing, 1(3), 30-42.

13. de Jager, J., \& Gbadamosi, G. (2013). Predicting students' satisfaction through service quality inhigher education. International Journal of Management Education, 11(3), 107-118. https://doi.org/10.1016/j.ijme.2013.09.001

14. Dehghan, A., Dugger, J., Dobrzykowski, D., \& Balazs, A. (2014). The antecedents of student loyalty in online programs. International Journal of Educational Management, 28(1), 15-35. https://doi.org/10.1108/IJEM-012013-0007

15. Đonlagić, S., \& Fazlić, S. (2015). Quality assessment in higher education using the servqual model. 
Management, 20(1), 39-57.

16. El Alfy, S., \& Abukari, A. (2019). Revisiting perceived service quality in higher education: uncovering service quality dimensions for postgraduate students. Journal of Marketing for Higher Education, 0(0), 1-25. https://doi.org/10.1080/08841241.2019.1648360

17. Elliott, K. M., \& Healy, M. A. (2001). Key Factors Influencing Student Satisfaction Related to Recruitment and Retention. Journal of Marketing for Higher Education, 10(4), 1-11. https://doi.org/10.1300/J050v10n04

18. Espejel, J., Fandos, C., \& Flavián, C. (2008). Consumer satisfaction: A key factor of consumer loyalty and buying intention of a PDO food product. British Food Journal, 110(9), 865-881. https://doi.org/10.1108/00070700810900585

19. Fitzsimmons, J. A., \& Fitzsimmons, M. J. (2011). Service Management: Operations, Strategy, Information Technology (7th ed.). New York: McGraw-Hill Company, Inc.

20. Galeeva, R. B. (2016). SERVQUAL application and adaptation for educational service quality assessments in Russian higher education. Quality Assurance in Education, 24(3), 329-348. https://doi.org/10.1108/mbe.2000.26704caa.006

21. Helgesen, Ø., \& Nesset, E. (2007). What accounts for students' loyalty? Some field study evidence. International Journal of Educational Management, 21(2), 126-143. https://doi.org/10.1108/09513540710729926

22. Hill, F. M. (1995). Managing service quality in higher education: The role of the student as primary consumer. Quality Assurance in Education, 3(3), 10-21. https://doi.org/10.1108/09684889510093497

23. Hoffman, K. D., \& Bateson, J. E. G. (2011). Services Marketing: Concepts, Strategies, \& Cases. Mason: SouthWestern Cengage Learning.

24. Hollins, B., \& Shinkins, S. (2006). Managing Service Operations Design and Implementation. London: SAGE Publications, Inc.

25. Keillor, B. D., Wilkinson, T. J., \& Thomas, A. R. (Eds.). (2007). Marketing In The 21st Century: New World Marketing. Westport: Greenwood Publishing Group, Inc.

26. Khoo, S., Ha, H., \& McGregor, S. L. T. (2017). Service quality and student/customer satisfaction in the private tertiary education sector in Singapore. International Journal of Educational Management, 31(4), 430-444. https://doi.org/10.1108/IJEM-09-2015-0121

27. Latif, K. F., Latif, I., Farooq Sahibzada, U., \& Ullah, M. (2019). In search of quality: measuring Higher Education Service Quality (HiEduQual). Total Quality Management and Business Excellence, 30(7-8), 768791. https://doi.org/10.1080/14783363.2017.1338133

28. Li, R. Y., \& Kaye, M. (1998). A case study for comparing two service quality measurement approaches in the context of teaching in higher education. Quality in Higher Education, 4(2), 103-113.

29. Lin, S. P., Chan, Y. H., \& Tsai, M. C. (2009). A transformation function corresponding to IPA and gap analysis. Total Quality Management and Business Excellence, 20(8), 829-846. https://doi.org/10.1080/14783360903128272

30. Martín-Consuegra, D., Molina, A., \& Esteban, Á. (2007). An integrated model of price, satisfaction and loyalty: An empirical analysis in the service sector. Journal of Product and Brand Management, 16(7), 459-468. https://doi.org/10.1108/10610420710834913

31. Mudie, P., \& Cottam, A. (1993). The Management and Marketing of Service. Oxford: Butterworth-Heinemann, Ltd.

32. Nadiri, H., Kandampully, J., \& Hussain, K. (2009). Students' perceptions of service quality in higher education. Total Quality Management \& Business Excellence, 20(5), 523-535. https://doi.org/10.1080/14783360902863713

33. O’Neill, M. A., \& Palmer, A. (2004). Importance-performance analysis: A useful tool for directing continuous quality improvement in higher education. Quality Assurance in Education, 12(1), 39-52. https://doi.org/10.1108/09684880410517423

34. Oliver, R. L. (1977). Effect of expectation and disconfirmation on postexposure product evaluations: An alternative interpretation. Journal of Applied Psychology, 62(4), 480-486. https://doi.org/10.1037/00219010.62.4.480

35. Oliver, R. L. (1980). A cognitive model of the antecedents and consequences of satisfaction decisions. Journal of Marketing Research, 14(4), 460-469. https://doi.org/10.2307/3150499

36. Osman, A. R., \& Saputra, R. S. (2019). A pragmatic model of student satisfaction: a viewpoint of private higher education. Quality Assurance in Education, 27(2), 142-165. https://doi.org/10.1108/QAE-05-2017-0019

37. Parasuraman, A., Zeithaml, V. A., \& Berry, L. L. (1985). A conceptual model of service quality and its implications for future research. Journal of Marketing, 49(4), 41-50. 
38. Parasuraman, A., Zeithaml, V. A., \& Berry, L. L. (1988). SERVQUAL: a multiple-item scale for measuring consumer perceptions of service quality. Journal of Retailing, 64(1), 12-40.

39. Perry, J. L., \& Thomson, A. M. (2004). Civic Service: What Difference Does it Make? New York: M. E. Sharpe.

40. Sharabati, A. A. A., Alhileh, M. M., \& Abusaimeh, H. (2019). Effect of service quality on graduates' satisfaction. Quality Assurance in Education, 27(3), 320-337. https://doi.org/10.1108/QAE-04-2018-0035

41. Smith, G., Smith, A., \& Clarke, A. (2007). Evaluating service quality in universities: a service department perspective. Quality Assurance in Education, 15(3), 334-551.

42. Śtimac, H., \& Šimić, M. L. (2012). Competitiveness in higher education: A need for marketing orientation and service quality. Economics and Sociology, 5(2), 23-34. https://doi.org/10.14254/2071-789X.2012/5-2/2

43. Stodnick, M., \& Rogers, P. (2008). SERVQUAL to measure the quality of the classroom experience. Decision Sciences Journal of Innovative Education, 6(1), 115-133.

44. Sultan, P., \& Wong, H. Y. (2013). Antecedents and consequences of service quality in a higher education context: A qualitative research approach. Quality Assurance in Education, 21(1), 70-95. https://doi.org/10.1108/09684881311293070.

45. Sumaedi, S., Bakti, I. G. M. Y., Rakhmawati, T., Astrini, N. J., Widianti, T., \& Yarmen, M. (2016). Factors influencing public transport passengers' satisfaction: a new model. Management of Environmental Quality: An International Journal, 27(5), 585-597. https://doi.org/10.1108/MEQ-05-2015-0084

46. Sunder, M. V. (2016). Constructs of quality in Higher Education services. International Journal of Productivity and Performance Management, 60(6), 6-21. Retrieved from http://dx.doi.org/10.1108/17410401111140374\%5Cnhttp://dx.doi.org/10.1108/17410400810841209\%5Cnhttp:/ /dx.doi.org/10.1108/02756661211281507

47. Tan, K. C., \& Kek, S. W. (2004). Service quality in higher education using an enhanced SERVQUAL approach. Quality in Higher Education, 10(1), 17-24. https://doi.org/10.1080/1353832242000195032

48. Teeroovengadum, V., Kamalanabhan, T. J., \& Seebaluck, A. K. (2015). Measuring service quality in higher education: development of a hierarchical model (HESQUAL). Quality Assurance in Education, 24(2), 244-258.

49. Uka, A. (2014). Student satisfaction as an indicator of quality in higher education. Journal of Educational and Instructional Studies, 4(3), 2146-7463. Retrieved from www.ijonte.org

50. Yildiz, S. M., \& Kara, A. (2015). Developing Alternative Measures for Service Quality in Higher Education: Empirical Evidence from the School of Physical Education and Sports Sciences. Proceedings of the 2009 Academy of Marketing Science (AMS) Annual Conference. Retrieved from https://link.springer.com/chapter/10.1007/978-3-319-10864-3_102

51. Zafiropoulos, C., \& Vrana, V. (2008). Service quality assessment in a greek higher education institute. Journal of Business Economics and Management, 9(1), 33-45. https://doi.org/10.3846/1611-1699.2008.9.33-45

52. Zeithaml, V. A., Parasuraman, A., \& Berry, L. L. (1990). Delivering Quality Service: Balancing Customer Perceptions and Expectation. New York: The Free Press. 